\title{
OPEN Author Correction: A dog oviduct- on-a-chip model of serous tubal intraepithelial carcinoma
}

\section{Marcia de Almeida Monteiro Melo Ferraz $\mathbb{D}^{0}$, Jennifer Beth Nagashima, Bastien Venzac, Séverine Le Gac \& Nucharin Songsasen}

Correction to: Scientific Reports https://doi.org/10.1038/s41598-020-58507-4, published online 31 January 2020

This Article contains an error in Figure 4 where the labels PAX8 and PTEN on the $\mathrm{x}$-axis were reversed. The correct Figure 4 appears below as Figure 1 .

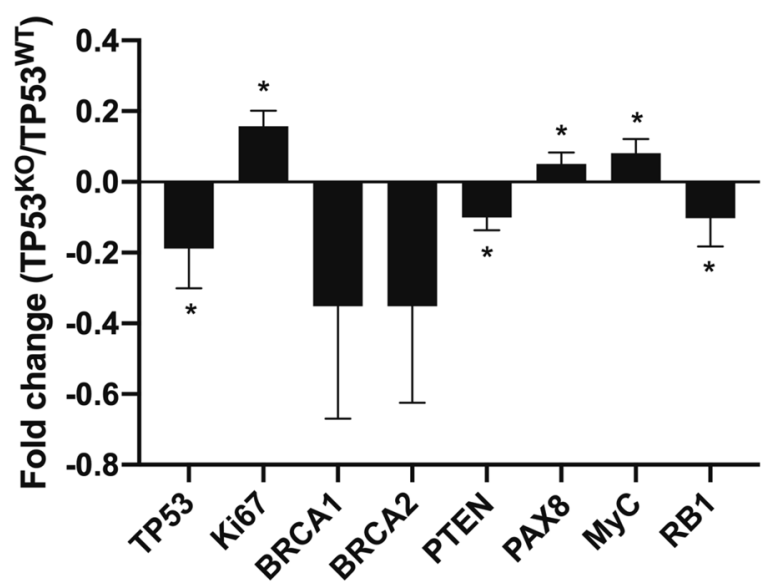

Figure 1.

(i) Open Access This article is licensed under a Creative Commons Attribution 4.0 International License, which permits use, sharing, adaptation, distribution and reproduction in any medium or format, as long as you give appropriate credit to the original author(s) and the source, provide a link to the Creative Commons license, and indicate if changes were made. The images or other third party material in this article are included in the article's Creative Commons license, unless indicated otherwise in a credit line to the material. If material is not included in the article's Creative Commons license and your intended use is not permitted by statutory regulation or exceeds the permitted use, you will need to obtain permission directly from the copyright holder. To view a copy of this license, visit http://creativecommons.org/licenses/by/4.0/.

(c) The Author(s) 2020 